\title{
Pathophysiology and Pharmacotherapy of Spasmodic Torticollis: A Review
}

\author{
S. LAL
}

SUMMARY: The few existing neuropathological, neurochemical, and neuropharacological studies have shed little light on the pathophysiology of spasmodic torvicollis $(S T)$. The relevance of experimental $S T$ in animals and drug-induced $S T$ in man to idiopathic ST is unclear.

Most pharmacotherapeutic endeavors have focused on drugs affecting basal ganglia function. Unfortunately, problems of sample size, clinical heterogeneity of patient population, research design, object-

RESUME: Les rares études neuropathologiques, neurochimiques et neuropharmacologiques connues ne jettent que peu de lumière sur la physiopathologie du torticollis spasmodique (ST). La correspondance entre le ST expérimental chez l'animal, le STinduit par des médicaments, et le ST idiopathique humain est encore inconnue.

La plupart des essais pharmacothérapeutiques se sont concentrés sur les médicaments agissant sur les fonctions des noyaux gris centraux. Plusieurs problèmes rendent l'interprétation des résultats pu- ive evaluation of response, documentation of key data, and adequacy of duration of follow-up make interpretation of published results difficult. Because of the heterogeneity of $S T$, investigations aimed at establishing a neurotransmitter profile for each patient by observing the acute response to a test dose of drugs affecting cholinergic. dopaminergic, serotonergic, and gammaaminobutyric acid systems may provide a more rational basis to the selection of treatment.

bliés alléatoire: grandeur de l'échantillonnage, hétérogénéité clinique des populations, plans de recherches, évaluation objective des réponses, documentation de données-clef, pertinence de la durée d'observation. A cause de l'hétérogénéité du $S T$, nous croyons qu'une batterie de tests qui aurait pour but d'évaluer, chez chaque patient, la réponse aiguï à des doses-essai de divers médicaments cholinergiques, dopaminergiques, sérotoninergiques et GABAergiques, offrirait une base plus valable pour la sélection du traitement approprié.
From the Department of Psychiatry, Montreal General Hospital, Montreal

Reprint requests to: Dr. S. Lal, Department of Psychiatry, Montreal General Hospital, 1650 Cedar Street, Montreal, Quebec H3G 1A4, Canada.

\section{INTRODUCTION}

"Spasmodic torticollis is an involuntary hyperkinesis manifesting itself by mobile, tonic or clonic spasms of the neck musculature, and producing a more or less stereotyped deviation of the head into an abnormal position, the chin being rotated to one side or the head bent directly forward (antecollis) or backward (retrocollis)" (Patterson and Little, 1943). The etiology and site of a presumed central nervous system (CNS) lesion is unknown. Most pharmacotherapeutic endeavors have focused on drugs that affect basal ganglia function. Unlike Parkinson's disease and Huntington's chorea where anatomical, chemical, and pharmacological information may provide a rational basis for therapy, such an underpinning of knowledge in spasmodic torticollis (ST) is lacking. Drug treatment is both advanced and discounted yet published results are few, contradictory, poorly controlled, and often inadequately documented.

The present paper discusses the pathophysiology of ST and reviews in detail the available literature on the pharmacotherapy of this disorder.

\section{PATHOPHYSIOLOGY OF ST}

\section{Neuroanatomical findings}

Psychological factors play a doubtful role in the etiology of ST (Marsden, 1976; Mathews et al., 1978; Cockburn, 1971; Choppy-Jacolin et al., 1977). On the other hand, demonstration of a consistent pathological lesion remains elusive. Necropsy studies have been few. Lesions in the striatum, amongst other sites, have been described in three autopsied brains (Grinker and Walker, 1933; Foerster, 1933; Alpers and Drayer, 1937) as well as in two cases in which ST was part of a genera- 
lized dystonia (Cassirer, 1922; Wimmer, 1929). However, the relevance of these findings to the development of ST is questioned (Tarlov, 1970). ST has been associated with injury to the cerebral cortex (David et al., 1952), colloid cyst of the third ventricle (Avman and Arasil, 1969), as well as with posterior fossa tumors (Winther. 1930; Boisen, 1979). In the latter, clonic features were not described. These symptomatic cases may indicate that lesions at several levels of the CNS may induce a clinical picture of ST. However, in the majority of cases of ST there is no demonstrable lesion.

Hassler and Dieckman (1970) found significant differences in cerebral hemispheric size on pneumoencephalography in $85 \%$ of cases. They speculated that these radiological findings indicated early brain damage which destroyed parts of the putamen (or projections to the putamen) which exert an inhibitory effect on contraversive head movements. This inhibitory action may become ineffective and ST become manifest. Unfortunately, the incidence of hemispheric asymmetry in subjects without ST was not given.

\section{Experimental $S T$}

Focal brain stems lesions have been known to produce abnormal neck postures in experimental animals (Foltz et al., 1969; Carpenter, 1956; Denny-Brown, 1962; Poirier, 1960; Mori et al., 1975; Battista et al., 1976; Carrea and Mettler, 1955). Interruption of ascending dopamine (DA) fibers from the midbrain tegmentum in the marmoset induces severe torticollis with deviation of the head towards the side of the lesion, but lesions in the pontine tegmentum, which affect ascending noradrenergic neurons, induce contralateral torticollis (Crossman and Sambrook, 1978). Tarlov (1970), examined brain regions that have been implicated in the experimental pathophysiology of ST, but found no histological abnormalities in the single ST brain investigated.

\section{Biochemical studies in $S T$}

The absence of anatomical changes does not exclude a biochemical lesion. A few investigations have focused on neuro-transmitter metabolism. Curzon (1973) found a normal mean concentration of homovanillic acid (HVA) and 5-hydroxyindoleacetic acid in lumbar cerebrospinal fluid (CSF) of 9 patients, whereas in a single case reported by Johansson and Roos (1974) there was a lowered value of both acids. In ventricular CSF from 4 patients with ST and 2 with dystonia musculorum deformans, HVA concentrations were intermediate between non-neurological controls and Parkinsonian patients (Papeschi et al., 1972).

\section{Endocrinological findings in $S T$}

ST may develop as a consequence of hyperthyroidism and resolve with treatment of the endocrine dysfunction (Gilbert, 1972a). Thyroxine increases catecholamine receptor sensitivity, but whether such a mechanism accounts for the precipitation of ST in a predisposed individual remains conjectural. In a single case of ST, apomorphine, a DA receptor agonist, failed to increase growth hormone secretion (Brown et al., 1973). The significance of this isolated finding is unclear.

\section{Neuropharmacological studies in ex- perimental $S T$}

Neurotransmitter dysfunction has been investigated in experimental ST, but results do not lend themselves to ready conclusions. Based on experiments in the monkey (Macaca mulatta), in which ST was produced by electrolytic lesions in the mesencephalic tegmentum, Foltz et al. (1959) postulated that a denervation hypersensitivity of acetylcholine neurons which control postural movements of the head and neck was important in the genesis of ST. However, anticholinergic agents failed to improve the experimental disorder. Anticholinergics, L-dopa, piribedil (indirectly acting DA receptor agonists), and apomorphine were ineffective in improving ST induced by ventromedial mesencephalic tegmental lesions in the African green monkey (Battista et al., 1976). Worsening of symptoms with these agents was not described. On the other hand, the DA receptor blockers haloperidol or pimozide, the catecholamine synthesis inhibitor, alphamethyl-para-tyrosine, as well as choli- nergic agents and drugs that enhance gamma-aminobutyric acid (GABA) function improved ST.

In the marmoset, in which the ascending DA fibers projecting from the mesencephalic tegmentum to the ipsilateral striatum were lesioned with 6-hydroxy-DA, amphetamine, an indirectly acting DA receptor agonist, worsened ST. Low doses of apomorphine, which may inhibit DA neurotransmission (in contrast to large doses, Tolosa, 1978), alleviated the experimental condition. High doses of apomorphine reversed the direction of ST (Crossman and Sambrook, 1978).

In the mid-brain lesioned cat the 5HT precursor, 5-hydroxytryptophan, worsened ST and L-dopa had no effect (Mori et al., 1975).

\section{Drug-induced $S T$ in man}

Neuroleptics (Ayd, 1961) as well as the benzamide derivative, metoclopramide (Casteels-van Daele et al., 1970) block DA receptors and induce a variety of dystonic reactions including ST in the early stages of treatment. Clinically, acute drug-induced ST is predominantly tonic in nature. Swett (1975) reported torticollis occurring in 35 out of 1152 patients receiving neuroleptics. In 20 cases of acute phenothiazine toxicity in childhood, four had torticollis (Gupta and Lovejoy, 1967). These dystonic reactions responded rapidly to anticholinergic agents (DiMascio et al., 1976), antihistamines (Gupta and Lovejoy, 1967; Cottom and Newman, 1966), which are also potent anticholinergic agents, as well as to the indirectly acting DA receptor agonists, amantadine (DiMascio et al., 1976) and methylphenidate (Fann, 1966).

ST may also develop as an isolated complication of chronic neuroleptic therapy (Chateau et al., 1966; Harenko, 1967) and can be considered as a form of tardive dyskinesia. However, whether chronic neuroleptic-induced ST pharmacologically resembles the more commonly studied oral form of tardive dyskinesia [i.e. worsening with anticholinergics and DA activating agents, but improvement with cholinergics and drugs that impair DA function (Marsden et al., 1976)] which is the opposite of acute neurolepticinduced ST, has not been well studied. 
In a single case, doses of neuroleptic sufficient to induce Parkinsonism eliminated chronic neuroleptic-induced ST (Chateau et al., 1966). "Parkinsonism medication" was ineffective in 6 patients with retrocollis associated with chronic neuroleptic use (Harenko, 1967).

In addition to chronic neuroleptic treatment which is believed to induce striatal DA super-sensitivity (Marsden et al., 1975), chronic treatment with Ldopa, in Parkinsonian patients at least, may also induce ST (Barbeau et al., 1971; Sigwald and Raymondeaud, 1970). This may suggest that enhanced DA function induces ST. However, improvement of acute neurolepticinduced ST with drugs that enhance DA function points to the complexity of relating drug-induced ST to idiopathic ST. Nevertheless, drug-induced dystonic reactions resemble spontaneously occurring movement disorders (Marsden et al., 1976; Ayd, 1961) so that it is difficult to believe that they are entirely without relevance to the pathophysiology of idiopathic dystonias, including ST.

\section{Neuropharmacological studies in idio- pathic $S T$}

Few data are available on the effect of test doses of drugs on ST. Hirschmann and Mayer (1964) in an open study found that L-dopa ( $25 \mathrm{mg}$ iv) improved all 6 patients with ST including one subject who had associated truncal dystonia. Surprisingly, the beneficial effects lasted up to three days. Tolosa (1978), in a predominantly uncontrolled investigation, noted transient improvement (45-60 mins) in 2 out of 7 patients following apomorphine (1-3 $\mathrm{mg} \mathrm{sc}$ ). In a placebocontrolled observation with film recording in one patient and uncontrolled observations in another, amphetamine $(30 \mathrm{mg} \mathrm{im}$ ) induced $\mathrm{im}$ provement within 30 mins on several different occasions which lasted 18-24 hrs. (Myerson and Loman, 1942). These three reports suggest that in some patients DA function is impaired.

Improvement has also been noted after diazepam ( $5 \mathrm{mg}$ iv), which enhances GABA function, but not the antihistamine, diphenhydramine (50 $\mathrm{mg}$ iv), (Bianchine and Bianchine,
1971). Unfortunately, the diagnosis in this single case report remains in doubt. Meprobamate administered over two days in combination with behavior therapy has resulted in amelioration in one patient (Turner et al., 1974), but improvement continued with behavior therapy alone.

\section{PHARMACOTHERAPY OF IDIOPATHIC ST}

\section{General Comments}

Table 1 summarizes the findings of 42 drug treatment trials reported in 33 papers published between 1937-1978 involving approximately 148 individuals. It would appear that 64 of the patients derived clinically significant improvement with drug therapy. Unfortunately, the data are limited in many respects and problems of interpretation are many.

(i) sample size

ST is a relatively uncommon disorder, though basic data on the incidence and prevalence are unknown. Of 42 drug treatment trials, 17 described results in only 1 or 2 patients, 16 in 5 or more and of the latter only 5 reported on series of 10 or more subjects.

(ii) clinical heterogeneity

In a variable number of patients with ST there is a family history of essential tremor, coexisting signs of essential tremor, facial spasms and tics, extranuchal dystonic features, and Parkinsonian symptoms (Patterson and Little, 1943; Couch, 1976b; Marsden, 1976; Critchley, 1939). In others there is a history of encephalitis (Patterson and Little, 1943) or the ST is a manifestation of idiopathic torsion dystonia (Marsden, 1976). In addition, abnormal CSF protein patterns are found in some patients but not in others (Kjellin and Stibler, 1975). Studies on ST include a mixture of patients from this broad clinical spectrum. How far this heterogeneity reflects different etiologies of ST or accounts for dramatic responses to pharmacotherapy in some patients but lack of response in others is unknown. Also, how far the inclusion of postthalotomy cases influences outcome to drug treatment is uncertain. In many reports little or no clinical data are given (Table 1).

\section{(iii) research design}

Evaluation of treatment should take into account the natural history of the disorder. Meares (1971), in a retrospective study, observed 4 remissions lasting 18 mos - $29 \mathrm{yrs}$ in 24 unoperated patients during the first year of the disorder and Mathews et al (1978) reported complete or substantial remission in 5 out of 30 patients in the first year of illness. Beyond a year of the disorder, spontaneous remissions are still possible (Meares, 1971; Mathews et al., 1978). In addition, fluctuations in intensity of the symptoms may vary from day to day or hour to hour. Also, the involuntary movements are sensitive to stress as well as to a variety of sensory stimuli (Podvinsky, 1969; Herz and Glazer, 1949). Hence, in the absence of control procedures, interpretation of results is difficult. Of 42 drug treatment reports in Table 1 , only 2 have utilized a double-blind placebocontrolled technique (West, 1977; Couch, 1976a). In both, a cross-over design was used. In a further 6 reports, placebo substitution was used but not systematically in all individuals. In 2 other reports, the design involved placebo substitution but only if improvement occurred. In an additional 8 reports, the effect of dose reduction or drug discontinuation was described but not in all subjects. The study of Couch (1976a) is the only one which provides a statistical analysis of results.

Only in exceptional cases are treatment observations beyond 3 mo described. In only 7 patients has this extended to 1 year or more and of these in only 2 subjects was the effect of drug discontinuation, dose reduction, or placebo substitution reported. (iv) objecrive evaluation of improvement

Objective assessment of severity of $S T$ is difficult and evaluation is usually limited to clinical impression. Collateral information is sometimes sought (West, 1977). Couch (1976a) used a clinical rating scale of frequency and severity of symptoms and Tolosa (1978) recorded the duration of keeping the head vertical. Film has been used in a few studies but only Swash et al. (1972) and Turner et al. (1974) described the method or process of evaluation. Filming permits 
TABLE 1.

Pharmacotherapy of Spasmodic Torticollis (ST)

\begin{tabular}{|c|c|c|c|c|c|c|}
\hline Treatment & Dose $^{1}$ & $\mathbf{N}^{4}$ & Results & $\mathbf{O B S}^{6}$ & Comments $^{7}$ & Authors \\
\hline $\begin{array}{l}\text { 1. Anti-cholinergics } \\
\text { Scopolamine }\end{array}$ & $?$ & 1 & $\begin{array}{l}\text { Appreciable } \\
\text { improvement }\end{array}$ & $?$ & Post-encephalitic parkinsonism & $\begin{array}{l}\text { Urechia \& } \\
\text { Retezeanu, } 1937\end{array}$ \\
\hline Scopolamine & $?$ & 17 & $\begin{array}{l}\text { None-slight } \\
\text { improvement }\end{array}$ & $?$ & & $\begin{array}{l}\text { Patterson \& } \\
\text { Little, } 1943\end{array}$ \\
\hline $\begin{array}{l}\text { Atropine (+ Sodium } \\
\text { Iodide) }\end{array}$ & $?$ & 1 & $\begin{array}{l}\text { Favorable } \\
\text { improvement }\end{array}$ & 5-6 mo & $\begin{array}{l}\text { Duration ST few dy; only partial } \\
\text { relapse on stopping drug. }\end{array}$ & Krebs, 1939. \\
\hline $\begin{array}{l}\text { Miscellaneous } \\
\text { (CT-237, P-189 } \\
\text { Cycrimine; } \\
\text { Scopolamine) }\end{array}$ & $\operatorname{Var}^{2}$ & 5 & $\begin{array}{l}2 \text { Sustained } \\
\text { improvement }\end{array}$ & $\begin{array}{l}1 \mathrm{yr} \\
21 / 2 \mathrm{yr}\end{array}$ & $\begin{array}{l}\text { Duration ST } 4 \text { mo; effect of } \\
\text { stopping drug not reported } \\
\text { Post-chicken pox encephalitis; } \\
\text { worsened on dose decrease }\end{array}$ & $\begin{array}{l}\text { Foltz et } \\
\text { al., } 1959\end{array}$ \\
\hline & & & $\begin{array}{l}3 \text { Transient } \\
\text { improvement }\end{array}$ & & $\begin{array}{l}\text { Dystonia musculorum deformans } \\
\text { in } 2\end{array}$ & \\
\hline Trihexyphenidyl & $?$ & $1^{5}$ & Remitted & $6 \mathrm{mo}$ & $\begin{array}{l}\text { Remission for } 10 \text { yr without } \\
\text { drugs; recurrence refractory }\end{array}$ & $\begin{array}{l}\text { Barrett et } \\
\text { al; } 1970\end{array}$ \\
\hline $\begin{array}{l}\text { 2. Cholinergics } \\
\text { Deanol }\end{array}$ & $450-900$ & 1 & No effect & 2 wk & & $\begin{array}{l}\text { Laterre \& } \\
\text { Fortemps, } \\
1975^{8}\end{array}$ \\
\hline
\end{tabular}

\section{Anti-dopaminergics}

Haloperidol (and/or

amantadine $300 \mathrm{mg} / \mathrm{dy}$ )

Haloperidol (+

Trihexyphenidyl

\pm Amantadine

\pm Diazepam)

Haloperidol

Haloperidol

Haloperidol

7

$1.5-14$

9-30

3

3

Prochlorperazine

Thioproperazine

Perphenazine

Pimozide

Tiapride
450

200

92-108

2

1 improved

1 no effect

? $2^{5} \quad 1$ transient improvement

200-500 4 No effect

All improved
3 wk-2 yr; In 2 duration of ST $\leqslant 6 \mathrm{mo}$; $<3$ mo 2 responded to amantadine alone in 3

$?$

2 markedly improved

$5^{5} \quad$ No effect

$6^{5} \quad 1$ dramatic improvement

5 no effect

8 improved

6 improved

$25-50 \%$

2 no change

Both improved

Few wk-

$2 \mathrm{yr}$

Few wk

Few wk
Gilbert, 1971, 1972a, 1972b, 1972c

All familial ST; also on

Gilbert 1977a biofeedback

Bigwood, $1972^{8}$

Shaw et al., 1972 stopping dru L-dopa.

All L-dopa failures

Double-blind cross-over; planned randomization of treatment sequence; assessment by rating scale

1 ? postencephalitic, with retrocollis

Sigwald et al., 1959

Sigwald et al., 1959 tution in 1

Blom \&

Retrocollis; torsion dystonia; relapse on dose decrease. Reserpine $4.5 \mathrm{mg} /$ dy; duration ST 6 mo

Siblings; 1 post-thalotomy with segmental dystonia
Ekbom, 1961

Korein, 1977

Emile et al., $1977^{8}$ 







\begin{tabular}{lccccc}
\hline Treatment & Dose $^{1}$ & $\mathbf{N}^{4}$ & Results & OBS $^{6}$ & Comments $^{7}$ \\
\hline Bromocriptine & $15-80$ & 10 & $\begin{array}{l}\text { 1 marked } \\
\text { improvement }\end{array}$ & $\begin{array}{l}\text { Authors } \\
\text { L-dopa. Single blind placebo } \\
\text { substitution. }\end{array}$ \\
& & 8 no effect & $>2$ mo & $\begin{array}{l}\text { Improved with haloperidol } \\
\text { (4.5 mg/day) - uncontrolled } \\
\text { Placebo substitution. }\end{array}$ \\
\hline
\end{tabular}

\begin{tabular}{l}
$\begin{array}{l}\text { 5. Serotonergics } \\
\text { L-5-hydroxytryptophan } \\
\text { ( Amantadine) }\end{array}$ \\
\hline
\end{tabular}

\begin{tabular}{|c|c|c|c|c|c|c|}
\hline \multicolumn{7}{|l|}{ 6. Gaba-ergics } \\
\hline Diazepam & $6-15$ & 6 & $\begin{array}{l}\text { Excellent } \\
\text { results }\end{array}$ & 5 dy-6 wk & $\begin{array}{l}\text { Type of torticollis unspecified. } \\
5 \text { 'acute', } 1 \text { chronic }\end{array}$ & $\begin{array}{l}\text { Pernikoff, } \\
1964^{8}\end{array}$ \\
\hline Diazepam & 8 & 1 & Recovered & $2 \mathrm{wk}$ & $\begin{array}{l}\text { Duration ST } 8 \text { days. Improve- } \\
\text { ment maintained on stopping } \\
\text { drug. }\end{array}$ & $\begin{array}{l}\text { Bianchine \& } \\
\text { Bianchine } 1971\end{array}$ \\
\hline $\begin{array}{l}\text { L-Glutamine + } \\
\text { Diazepam + } \\
\text { Isoniazid + } \\
\text { Pyridoxine }\end{array}$ & see text & $2^{5}$ & $\begin{array}{l}1 \text { symptom } \\
\text { free }\end{array}$ & $>2 \mathrm{mo}$ & $\begin{array}{l}\text { Siblings; non-responder post- } \\
\text { thalotomy and segmental } \\
\text { dystonia }\end{array}$ & Korein, 1977 \\
\hline
\end{tabular}

\begin{tabular}{|c|c|c|c|}
\hline Lithium & $\begin{array}{l}\text { serum } \\
\text { Li } 0.9 \\
\mathrm{mM} / 1\end{array}$ & 3 & $\begin{array}{l}\text { Striking } \\
\text { improvement } \\
\text { in all }\end{array}$ \\
\hline
\end{tabular}

$\begin{array}{llll}\text { Lithium } & 1200 \quad 1 \quad \text { Improved }\end{array}$

Abnormal CSF protein patterns.
Single blind placebo substi-
tution in 2 . Duration ST
2 mo in 1.
Single blind placebo substitu-
tion; independent evaluators.
Prior town gas poisoning \&
neuroleptic therapy.

Kjellin \&

Stibler, 1975 Single blind placebo substi-

Stibler, 1975

Couper-

Smartt, 1973 Prior town gas poisonit
neuroleptic therapy.

$\begin{array}{lllll}\text { Lithium } & ? & 2 & \text { Both responded } & ? \\ \text { Quinine } & \operatorname{Max}^{3} & 6 & \text { No benefit }\end{array}$

Gilbert, $1977 b^{8}$

Patterson and Little $1943^{8}$



\footnotetext{
'Maximum or optimum daily dose in mg/day unless specified. ${ }^{2}$ Various combinations; names of coded drugs CT-237 and P-189 not given. ${ }^{3}$ Maximum tolerated dose.

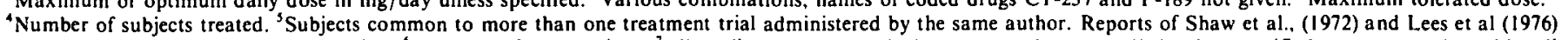

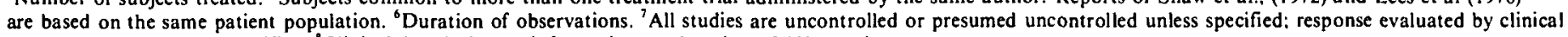
assessment alone unless specified. ${ }^{8}$ Clinical description or information on duration of ST not given.
}

frequency counts but amplitude is more difficult to assess. Use of a horizontal grid over a videotape television monitor has been described (Bernhardt et al., 1972), but this has not yet been used in pharmacotherapeutic investigations. Ansari and Webster (1974) described recording devices to quantify head rotation and head tremor in ST, but these have not been widely used (Ansari et al., 1972). Unfortunately, a single recording by whatever technique may not provide an accurate sample of the actual treatment response. Sustained im- provement on several measures, namely, on clinical assessment, range of daily activities, collateral information, and an objective recording is required to document improvement, but this is rarely done.

Treatment may result in worsening of the tonic but improvement of the spasmodic component or vice-versa. Whether such change is considered amelioration, deterioration, or no effect depends on the requirements of the individual in his day to day activities.

In the absence of objective mea- sures, side effects reported by the patient may be mistaken for worsening of ST. Improvement may result from non-specific sedative effects rather than from a presumed selective pharmacological action.

\section{Effect of anticholinergic agents}

Bunts (1960) stated, without details, that treatment with anticholinergic drugs (scopolamine, trihexyphenidyl, and cycrimine) was discouraging and Patterson and Little (1943) found slight to no effect in 17 patients treated with scopolamine. In the absence of 
details one can only conjecture that dose and duration of treatment in the latter study were adequate. In contrast, Putnam et al. (1949) recommended atropine for several months and Poppen and Martinez-Niochet (1951) suggested scopolamine before considering surgery. One presumes that some patients were improved by this approach, but the number of subjects treated and the outcome were not given.

Mild relief with benztropine has been incidentally noted (Gilbert, 1972a), but otherwise, apart from the single case reports of Barrett et al, (1970) and of Krebs (1939), in whom spontaneous remissions probably occurred, in only 3 patients has improvement been documented with anticholinergics (Urechia and Retezeanu, 1937; Foltz et al, 1959). Interestingly, in 2 of these 3 patients there was a history of encephalitis. In 2 patients of Foltz et al. (1959), sustained improvement over one year in 1 patient and 2.5 yrs in the other was described. In the former case, spontaneous improvement cannot be excluded as a dose reduction was not tried. In the latter case, several attempts at dose reduction resulted in relapse.

Anticholinergic drugs have frequently been used in combination with other pharmacotherapeutic agents to counteract side effects. The relevance to therapeutic outcome is difficult to assess. Myerson and Loman (1942) reported a potentiating effect of scopolamine on the beneficial effect of amphetamine in one patient and Gilbert (1977b) stated that the therapeutic effect of haloperidol was reduced by co-administration of anticholinergic agents.

\section{Effect of antidopaminergic agents}

DA receptor blockers as well as directly and indirectly acting DA receptor agonists are reported to improve some cases of ST. This apparent anomaly is further complicated by reports that haloperidol in combination with amantadine results in marked improvement (Gilbert, 1972a). The most convincing report of a therapeutic benefit from DA receptor blockers was from Couch (1976a) who used a placebo-controlled crossover study in 16 patients. The duration of treatment with the active agent, haloperidol, was 4 weeks. The effect of long-term treatment, however, remains to be documented. The failure with haloperidol reported by some authors (Bigwood, 1972; Shaw et al., 1972) may be due to inadequate doses. Gilbert (1972b; 1972c; 1977b) has emphasized that 14-30 $\mathrm{mg}$ or more per day may be needed and in addition coadministration of amantadine may be necessary for successful therapy (Gilbert, 1972a; 1972c; 1977a).

In 2 patients, one on prochlorperazine (Sigwald et al., 1959) and one on haloperidol, amantadine and, trihexyphenidyl (Gilbert, 1972a) improvement for at least 1 year was reported. In neither case was the response to drug withdrawal described.

It is possible that response to DA receptor blockers represents only masking of ST by induction of mild drug-induced Parkinsonism.

Results obtained with benzamide derivatives, depletors of central DA, or alpha-methyldopa show little that is encouraging.

\section{Effect of dopaminergic agents}

Putnam et al (1949) and Poppen and Martinez-Niochet (1951) recommended amphetamine as a pharmacological treatment before considering surgery. The former used a dose of $10 \mathrm{mg}$ twice daily. Outcome of this approach was not given. Myerson and Loman (1942) in 2 patients required considerably larger doses of amphetamine than used by Putnam et al (1949) to induce improvement. In two cases reported by Gilbert (1972a) amantadine alone was effective in treating ST. In other cases combination with haloperidol was necessary. In the only double blind study with amantadine no therapeutic effect was demonstrated (West, 1977). However, the dose in this controlled study was less than that found successful by Gilbert (1972a; 1972b). Studies with L-dopa have involved giving the drug to the maximum tolerated dose. In general, no effect or worsening has been reported (Ansari et al., 1972; Shaw et al., 1972; Barrett et al., 1970), though in a single well documented case remarkable improvement occurred on both L-dopa and bromocriptine (Lees et al, 1976) but not on placebo substi- tution. In one patient, worsening on bromocriptine was followed by improvement on haloperidol (Lees et al., 1976).

The use of DA activating agents resulting in improvement lasting one or more years has been described in only 3 patients, one on amphetamine combined with scopolamine (Myerson and Loman, 1942), one with amantadine (Gilbert, 1972a), and one on Ldopa (Shaw et al., 1972). Only in the latter was dose reduction, drug discontinuation, or placebo substitution reported.

\section{Effect of miscellaneous drugs}

Evaluation of drugs affecting GABAergic or $5 \mathrm{HT}$ function have been few. The diagnoses in the cases responding to diazepam described by Pernikoff (1964) and Bianchine and Bianchine (1971) are unclear. Incidental comments pointing to an ineffectual role of diazepam have been mentioned in the literature (Barnett et al., 1970; Gilbert, 1972a). Follow-up of the preliminary work of Korein (1977) who used large daily doses of L-glutamine (40G), diazepam (30mg), isoniazid (150mg), and pyridoxine (150mg) to enhance central GABAergic function is awaited.

All published reports on the use of lithium have found improvement (Kjellin and Stibler, 1975; Gilbert, 1977b; Couper-Smartt, 1973) though long term outcome has not been reported.

\section{POSSIBLE APPROACH TO THE TREATMENT OF ST}

The limited and in general poorly documented or conducted research makes any summary conclusion difficult. One possible point of focus worth considering is that ST is a heterogeneous disorder. This would account for the diversity of clinical findings as well as the variable pharmacotherapeutic responses reported. Some patients appear to respond to anticholinergic agents, some to DA receptor blockers, and some to DA receptor agonists though the total numbers may be small. If this is so then it may be possible to identify potential responders to these 3 classes of drugs by observing the response to a single dose of benztropine, haloperidol, or 
apomorphine, respectively, under controlled conditions. Recent findings suggest that a single intravenous dose of benztropine and, to a lesser extent, subcutaneous apomorphine may indeed identify potential responders to chronic benztropine or L-dopa therapy (Lal et al., 1979). This approach could be extended by evaluating potential responders to GABAergic and 5HT drugs by use of a single dose of diazepam or L-tryptophan, respectively. Studies establishing an individual profile of neurotransmitter function by such pharmacological tests may provide a more rational approach to the investigation and treatment of ST.

\section{ACKNOWLEDGEMENTS}

This work was supported by the Fund for Research in the Fields of Dyskinesia and Torticollis, Canada.

\section{REFERENCES}

ALPERS, B.J. and DRAYER, C.S. (1937). The organic background of some cases of spasmodic torticollis. Report of a case with autopsy. Am. J. Med. Sci., 193, 378-384.

ANSARI, K.A. and WEBSTER, D. D. (1974). Quantitative measurements in spasmodic torticollis. Dis. Nerv Syst., 35, 44-47.

ANSARI, K.A., WEBSTER, D. and MANNING, N. (1972). Spasmodic torticollis and L-dopa. Results of therapeutic trial in six patients. Neurology, 22, 670-674.

AVMAN, N. and ARASIL, E. (1969). Spasmodic torticollis due to a colloid cyst of the third ventricle. Acta Neurochir. (Wien), 21, 265-268.

AYD, F.J. (1961). A survey of drug-induced extrapyramidal reactions. J. Am. Med. Assoc., 175, 1054-1060.

BARBEAU, A., MARS, $H$. and GILLOJOFFROY, L. (1971). Adverse clinical side effects of levodopa therapy. In Recent Advances in Parkinson's Disease, Edited by F.H. McDowell and C.H. Markham, pp 203-237, F.A. Davis Co, Philadelphia.

BARRETT, R.E., YAHR, M.D. and DUVOISIN, R.C. (1970). Torsion dystonia and spasmodic torticollis-results of treatment with L-dopa. Neurology, 20, Suppl. 107-113.

BATTISTA, A.F., GOLDSTEIN, M., MIYAMOTO, T. and MATSUMOTO, Y. (1976). Effect of centrally acting drugs on experimental torticollis in monkeys. Adv. Neurol. 14. 329-338.

BERNHARDT, A.J., HERSEN, $M$. and BARLOW, D. H. (1972). Measurement and modification of spasmodic torticollis: an experimental analysis. Behav. Therap., 3, 294-297.
BIANCHINE, J.R. and BIANCHINE, J.W (1971). Treatment of spasmodic torticollis with diazepam. S. Med. J., 64, 893-894.

BIGWOOD, G.F. (1972). Treatment of spasmodic torticollis. New Engl. J. Med., 286, 1161.

BLOM, S. and EK BOM, K. A. (1961). Comparison between akathisia developing on treatment with phenothiazine derivatives and restless legs syndrome. Acta Med. Scand., $170,689-694$

BOISEN, E. (1979). Torticollis caused by an infratentorial tumour. Three cases. Brit. J Psychiat., 134, 306-307.

BROWN, W.A., VAN WOERT, M.H. and AMBANI, L.M. (1973). Effect of apomorphine on growth hormone release in humans. J. Clin. Endocrinol. Metab., 37, 463-465.

BUNTS, A.T. (1960): The surgical treatment of spasmodic torticollis. Am. Surg., 26, 560563.

CARPENTER, M. B. (1956). A study of the red nucleus in the rhesus monkey. Anatomical degenerations and physiological effects resulting from localized lesions of the red nucleus. J. Comp. Neurol., 105, 195-249.

CARREA, R.M.E. and METTLER, F.A. (1955). Function of the primate brachium conjunctivum and related structures. $J$. Comp. Neurol., 102, 151-322.

CASSIRER, R. (1922). Halsmuskelkrampf und Torsionsspasmus. Klin. Wschr., 1, 53-57.

CASTEELS-VAN DAELE, M., JAEKEN, J., VAN DER SCHUEREN, P., ZIMMERMAN, A. and VAN DEN BON. (1970). Dystonic reactions in children caused by metoclopramide. Arch. Dis. Child., 45, 130 133.

CHATEAU, R., FAU, R., GROSLAMBERT, R. and PERRET, J. (1966). Ȧ propos d'un cas de torticolis spasmodique irréversible, survenu au cours d'un traitement par neuroleptiques. Rev. Neurol. (Paris), 114, 65-68.

CHOPPY-JACOLIN, M., FERREY, G. and DEMARIA, C. (1977). A psychometric study of 34 patients afflicted with spasmodic torticollis. Acta Neurol, Scand., 55, 483-492.

COCKBURN, J.J. (1971). Spasmodic torticollis: a psychogenic condition? J. Psychosomat. Res., 15, 471-477.

COTTOM, D.G. and NEWMAN, C.G.H. (1966). Dystonic reactions to phenothiazine derivatives. Arch. Dis. Child., 41, 551-553.

COUCH, J.R. (1976a). General discussion of drug-therapy in dystonia. Adv. Neurol., 14, 417-422.

COUCH, J. R. (1976b). Dystonia and tremor in spasmodic torticollis. Adv. Neurol., 14, 245 258.

COUPER-SMARTT, J. (1973). Lithium in spasmodic torticollis. Lancet, 2, 741-742.

CRITCHLEY, M. (1939). Spastic dysphonia ("inspiratory speech"). Brain, 62, 96-103.

CROSSMAN, A.R. and SAMBROOK, M.A. (1978). Experimental torticollis in the monkey produced by unilateral 6-hydroxydopamine brain lesions. Brain Res., 149, 498-502.
CURZON, G. (1973). Involuntary movements other than Parkinsonism: biochemical aspects. Proc. Roy. Soc. Med. 66, 29-32.

DAVID, M. HECAEN, $H$. and CONSTANS, J. (1952). Torticolis spasmodique consécutif à une lésion corticale traumatique. Discussion du résultat favorable obtenu après excision de la lésion corticale. Rev. Neurol. (Paris), 86, 57-61.

DENNY-BROWN, D. (1962). The midbrain and motor integration. Proc. Roy. Soc. Med., 55, 527-538.

DIMASCIO, A., BERNADO, D. L. GREENBLATT, D. J. and MARDER, J.E. (1976) A controlled trial of amantadine in druginduced extrapyramidal disorders. Arch. Gen. Psychiat., 33, 599-602.

EMILE, J, BASTARD, J, and TRUELLE, JL. (1977). Utilisation du tiapride en neurologie. Résultats préliminaires. Sem. Hôp. (Paris), 53, 16-20.

FABING, H.D. (1954). Alpha-(2-piperidyl) benzhydrol hydrochloride, a new central stimulant, in the treatment of blepharospasm, spasmodic torticollis and narcolepsy. Tran. Am. Neurol. Ass., 79, 159-163.

FANN, W. E. (1966). Use of methylphenidate to counteract acute dystonic effects of phenothiazines. Am. J. Psychiat., 122, 1293-1294.

FOERSTER, O. (1933). Mobile spasm of the neck muscles and its physiological basis. $J$. Comp. Neurol. 58: 725-735.

FOLTZ, E.L., KNOPP, L.M. and WARD, A. A. (1959). Experimental spasmodic torticollis. J. Neurosurg., 16, 55-72.

GILBERT, G.J. (1971). Spasmodic torticollis treated effectively by medical means. New Engl. Med. J., 284, 896-898.

GILBERT, G.J. (1972a). The medical treatment of spasmodic torticollis Arch. Neurol., 27, 503-506.

GILBERT, G. J. (1972b). Haloperidol in spasmodic torticollis. Lancet, 2, 234-235.

GILBERT, G.J. (1972c). Treatment of spasmodic torticollis. New Engl. J. Med., 286, $1161-1162$.

GILBERT, G.J. (1977a). Familial spasmodic torticollis. Neurology, 27, 11-13.

GILBERT, G. J. (1977b). Treatment questioned in familial spasmodic torticollis. Reply from the author. Neurology, 27, 900.

GRINKER, R. R. and WALKER, A.E. (1933). The pathology of spasmodic torticollis with a note on respiratory failure from anesthesia in chronic encephalitis. J. Nerv. Ment. Dis., 78, 630-637.

GUPTA, J.M. and LOVEJOY, F.H. (1967). Acute phenothiazine toxicity in childhood: a five-year survey. Pediatrics, 39, 771-774.

HARENKO, A. (1967). Retrocollis as an irreversible late complication of neuroleptic medication. Acta Neurol. Scand. 43, Suppl. 31: 145-146.

HASSIN, G.B. (1939). Quinine and dystonia musculorum deformans. J. Am. Med. Assoc., 113, 12-14.

HASSLER, R. and DIEKMANN, G. (1970). Stereotactic treatment of different kinds of 
spasmodic torticollis. Confin. Neurol. 32 . 135-143.

HERZ, E. and GLASER, G.H. (1949). Spasmodic torticollis. II. Clinical evaluation. Arch. Neurol. Psychiat. 61, 227-239.

HIRSCHMANN, J. and MAYER, K. (1964). Zur Beeinflussung der Akinese und anderer extrapyramidal-motorischer Storungen mit L-Dopa (L-Dihydroxyphenylalanin). Deutsch. Med. Wschr., 89, 1877-1880.

JOHANSSON, B. and ROOS, B-E. (1974). 5Hydroxyind oleacetic acid and homovanillic acid in cerebrospinal fluid of patients with neurological diseases. Europ. Neurol., 11, $37-45$.

KJELLIN, K.G, and STIBLER, H. (1975). Cerebrospinal fluid protein patterns in spasmodic torticollis. Europ. Neurol., 13, 461-475.

KOREIN, J. (1977). Treatment questioned in familial spasmodic torticollis. Neurology, 27, 899-900.

KREBS, M.E. (1939). Note sur le traitement pratiqué dans un cas de torticolis spasmodique. Rev. Neurol. (Paris), 71, 423-424.

LAL, S., HOYTE, K.M., KIELY, M.E., SOURKES, T. L., BAXTER, D. W., MISSALA, K. and ANDERMANN, F. (1979). Neuropharmacological investigation and treatment of spasmodic torticollis. Adv. Neurol. (in press).

LATERRE, E. C. and FORTEMPS, E. (1975). Deanol in spontaneous and induced dyskinesias. Lancet, 1, 1301.

LEES, A., SHAW, K.M. and STERN, G.M. (1976). Bromocriptine and spasmodic torticollis. Brit. Med. J., 1, 1343.

MARK HAM, C. H., CLARK, W. G. and WINTERS, W.D. (1963). Effect of alpha-methyl dopa and reserpine in Huntington's chorea, Parkinson's disease and other movement disorders. Life Sci., 9, 697-705.

MARSDEN, C.D., TARSY, D. and BALDESSARINI, R.J. (1975). Spontaneous and drug-induced movement disorders in psychotic patients. In Psychiatric Aspects of Neurologic Disease, Edited by D. F. Benson and D. Blumer, pp219-266, Grune and Stratton, New York.
MARSDEN, C.D. (1976). The problem of adult-onset idiopathic torsion dystonia and other isolated dyskinesias in adult life (including blepharospasm, oromandibular dystonia, dystonic writer's cramp, and torticollis or axial dystonia. Adv. Neurol. 14, 259-276.

MATHEWS, W. B., BEASLEY, P., PARRYJONES, W. and GARLAND, G. (1978). Spasmodic torticollis: a combined clinical study. J. Neurol. Neurosurg. Psychiat., 4l, 485-492.

MEARES, R. (1971). Natural history of spasmodic torticollis and effect of surgery. Lancet, 2, 149-151.

MORI, K., FUJITA, Y., SHIMABUKURO, H., ITO, M. and HANDA, H. (1975). Some considerations for treatment of spasmodic torticollis. Clinical and experimental studies. Confin. Neurol. 37, 265-269.

MYERSON, A. and LOMAN, J. (1942). Amphetamine sulfate in treatment of spasmodic torticollis. Arch. Neurol. Psychiat., 48, 823-828.

PAPESCHI, R., MOLINA-NEGRO, P., SOURKES, T. L. and ERBA, G. (1972). The concentration of homovanillic acid and 5-hydroxyindoleacetic acid in ventricular and lumbar CSF. Neurology, 22, 1151-1159.

PATTERON, R.M. and LITTLE, S.C. (1943). Spasmodic torticollis. 98, 571-599.

PERNIKOFF, M. (1964). Treatment of acute and chronic muscle spasm with diazepam. Clin. Med. 71, 699-705.

PODVINSKY, F. (1969). Role of sensory and emotional inputs in mechanisms underlying involuntary motor activity. Modern concepts of torticollis. 1. Electromyographic analysis. Activ. Nerv. Sup. 11, 11-29.

POIRIER, L.J. (1960). Experimental and histological study of midbrain dyskinesias. $J$. Neurophysiol., 23, 534-551.

POPPEN, J.L. and MARTINEZ-NIOCHET, A. (1951). Spasmodic torticollis. Surg. Clin. N. Amer., 31, 883-890.

PUTNAM, T.J., HERZ, E. and GLASER, G. H. (1949). Spasmodic torticollis. 111 . Surgical treatment. Arch. Neurol. Psychiat. 61, 240-247.
SHAW, K. M., HUNTER, K. R. and STERN, G. M. (1972). Medical treatment of spasmodic torticollis. Lancet, I. 1399.

SIGWALD, J., BOUTTIER, D., MME. CAILLE and GINESET. D. (1959). Deux cas de syndrome dystonique et dyskinétique cervico-céphalique (torticolis spasmodique, retrocolis) transformé par le 2 bismethane sulfonate de diméthylsulfamido-3 [(méthyl-4 "piperazinyl-1") -3' propyl] -10 phénothiazine (7843R P). Rev. Neurol. (Paris), 100. 778-780.

SIGWALD, J. and RAYMONDEAUD, C. (1970). Les mouvements a normaux observés au cours du traitement de la maladie de Parkinson par la L-dopa. Rev. Neurol. (Paris), 122, 103-112.

SWASH, M., ROBERTS, A.H., ZAKKO, H. and HEATHFIELD, K. W. G. (1972). Treatment of involuntary movement disorders with tetrabenazine. J. Neurol. Neurosurg. Psychiat., 35, 186-191.

SWETT, C. (1975). Drug-induced dystonia. Am. J. Psychiat., 132, 532-534.

TARLOV, E. (1970). On the problem of pathology of spasmodic torticollis in man. J. Neurol. Neurosurg. Psychiat., 33, 457-463.

TOLOSA, E.S. (1978). Modification of tardive dyskinesia and spasmodic torticollis by apomorphine. Arch. Neurol., 35, 459-462.

TRILLET, M., JOYEUX, $O$. and MASSON, R. (1977). Tiapride et mouvements anormaux. Sem. Hôp. (Paris), 53, 21-27.

TURNER, S.M., HERSEN, M. and ALFORD, H. (1974). Effects of massed practice and meprobamate on spasmodic torticollis: an experimental analysis. Behav. Ther., 12, 259-260.

URECHIA, C.I. and MME RETEZEANU (1937). Parkinsonisme avec torticolis spasmodique ou avec tics buccaux. Arch. Neurol. (Paris), 56, 491-494.

WEST, H. H. (1977). Treatment of spasmodic torticollis with amantadine: a double-blind study. Neurology, 27, 198-199.

WIMMER, A. (1929). Le spasme de torsion. Rev. Neurol. (Paris), 1, 904-915.

WINTHER, K. (1930). Tumeur du quatrième ventricule, se manifestant seulement par une deviation de la tête. Acta Psychiat. Neurol., 5, 45-53. 